\title{
COMPARATIVE ASSESSMENT OF SEMEN PROFILE AND BIOCHEMICAL PARAMETERS AFTER TREATMENT WITH MUCUNA SPS. IN SPRAGUE DAWLEY RATS
}

\author{
Murthy $\mathrm{SN}^{1 *}$, Pawar $\mathrm{SD}^{1}$, Shirolkar $\mathrm{AR}^{1}$, Malgaonkar $\mathrm{MM}^{1}$, and Kulkarni $\mathrm{YR}^{2}$ \\ ${ }^{1}$ National Research Institute of Basic Ayurvedic Sciences, Kothrud, Pune, India. \\ ${ }^{2}$ Professor PDEA College of Ayurveda and Research Center, Pune, India.
}

\begin{abstract}
The different varieties of Kapikachu viz., Mucuna cochinchinensis (Lour.) A Chev. (Black seed variety), $M$. cochichinensis (Lour.) A Chev. (White seed variety) and M. pruriens (L.) DC. are used in the treatment of infertility in India by Ayurvedic physicians. The study was carried out for comparative assessment of their effect on semen profile and biochemical parameters in Sprague Dawley strain rats. The animals were treated with different dose of aqueous extract of $M$. cochinchinensis (Black seed variety), M. cochichinensis (White seed variety) and $M$. pruriens for the period of 30 days. The body weight, sperm count, sperm motility, morphology of sperm, serum levels of testosterone, estradiol, Luteinizing hormone (LH), and Total antioxidant capacity were measured. The testes were isolated, weighed and sectioned to study the histological changes. The results of the study showed the increase in sperm count, serum motility, levels of serum testosterone, $\mathrm{LH}$ and total antioxidant capacity in animals treated with aqueous extract of $M$. cochinchinensis (Black seed variety), followed by $M$. pruriens and $M$. cochichinensis (White seed variety). These observations were supported by histological change in testes. From the results obtained, it can be concluded that the $M$. cochinchinensis (Black seed variety) is more potent than other varieties of Kapikachu in rats.
\end{abstract}

Keywords: Spermatogenesis, Mucuna cochinchinensis (Lour.) A. Chev., Mucuna pruriens (L.) DC., L-dopa

\section{INTRODUCTION}

Ayurveda a traditional health care system believes in the philosophy of not only treating the diseases but also to help in maintaining the healthy state of every individual with the help of naturally available resources such as commonly available herbs, spices, minerals and animal products. Vrishya chikitsa is one of the eight branches of Ayurveda which is devoted to the treatment of infertility, impotence and other diseases related to the reproductive system in males.

Vrishya (Aphrodisiac) therapy helps in nourishing the body tissues of an individual with a target of improving the quality of germinative tissues. A drug or therapy which bestows off spring, immediate feeling of joy, the capacity to copulate with women with great vigour like a horse and becoming dearer to women thereby is known as Vajeekarana (Virilification) ${ }^{1}$ (A.S.Utta. Chapt 50/1-3). Kapikachu being known for its Vajeekarana activity, is selected in this study for assessment of its effect on spermatogenesis. Susruta used this for the first time for vajeekarana

*Corresponding author:

Email: snmurthy.rri@gmail.com

http://dx.doi.org/10.20530/IJTA 32_55-62

ISSN 2320-138X (c) 2016 purpose. Later on, the authors of all the Nighantus also mentioned this drug for vrishya chikitsa.

Recent studies also suggested that oral administration of Mucuna pruriens (L.) DC seed powder helps in reducing psychological stress and seminal plasma lipid peroxide levels along with improved sperm count and motility ${ }^{2}$. In another study has shown significant improvement in terms of sperm count, volume, and motility of sperm. It has shown mild improvement in non progressive sperm (NP) and no improvement in slow linear progress of (SLP) sperm ${ }^{3,4}$. In some other study $M$. pruriens and its major constituent L-Dopa has recovered the spermatogenic loss by combating ROS, loss of mitochondrial membrane potential and apoptosis 5 .

The present study was therefore aimed for comparative assessment of semen profile and biochemical parameters in Sprague Dawley rats using method described by Khaki et al. ${ }^{6}$ after treatment with different varieties of Kapikachu viz., Mucuna cochinchinensis (Lour.) A. Chev (Black seed variety), Mucuna cochichinensis (Lour.) A. Chev (White seed variety) and Mucuna pruriens (L.) DC. in Sprague Dawley strain rats.

\section{MATERIALS AND METHODS}

\section{Collection of plant material}

Healthy, fresh and disease free plant material seeds of Mucuna pruriens (L.) DC. and Mucuna 
cochinchinensis (Lour.) Chev. (White seed) were collected from NRIBAS, garden and local market of Pune (Maharashtra) respectively. Mucuna cochinchinensis (Lour.) Chev. (Black seed) collected from local market of Kerala.

\section{Authentication of plant material}

Crude drug were identified and authenticated by Agharkar Research Institute, Pune and deposited with voucher number, S-162 (Mucuna pruriens (L.) DC.), S-159 (Mucuna cochinchinensis (Lour.) A. Chev. (White seed)) and S-159 (Mucuna cochinchinensis (Lour.) A. Chev. (Black seed)).

\section{Elemental study}

Elemental studies of the samples collected from the market and fields were carried out in detail as per the standard methods. Analysis was outsourced to Maharashtra Rajya Draksha Bagaitdar Sangh (MRDBS), Manjari Farm, Pune. with stainless steel grill top, facilities for food and water bottle, with the bedding of clean paddy husk. The environmental conditions such as air conditioned experimental rooms with 10-15 air changes per hour, temperature between $21 \pm 2 \circ \mathrm{C}$, relative humidity $55 \pm 5 \%$ and illumination cycle set to 12 hours fluorescent light and 12 hours dark was maintained for animal house facility. Diet of the animals was "Nutrimix" brand pelleted standard rat feed Manufactured by Nutrivet Life Sciences, Pune was provided ad libitum. Potable water passed through reverse osmosis filtration system and exposed to U.V. ray was provided ad libitum in glass bottles with stainless steel sipper tubes. Sixty six male rats weighting between 250 270 gm were used.

\section{Ethical clearance:}

The study was carried out at Toxindia Contractual Research Organization, Pune, after

\section{Elemental study parameters}

\begin{tabular}{cll}
\hline Sr. No. & Analysis Parameter & Method for Analysis \\
\hline 1 & Total Nitrogen & Wet Digestion Followed by Kjeldahl distillation Method \\
2 & Nitrate Nitrogen & Phenol Disulphonic Acid Method \\
3 & Digestion & Diacid digestion $\left(\mathrm{HNO}_{3}: \mathrm{HClO}_{4}\right)-3: 1$ \\
4 & Phosphorous & Spectrophotometric Vanado Phospho Molybdate Method \\
5 & Potassium & Flame Photometric Method \\
6 & Calcium & Atomic Absorption Spectrophotometric Method \\
7 & Magnesium & Atomic Absorption Spectrophotometric Method \\
7 & Sulphur & Barium Chloride, Turbidimetric Method \\
9 & Iron & Atomic Absorption Spectrophotometric Method \\
10 & Manganese & Atomic Absorption Spectrophotometric Method \\
11 & Zinc & Atomic Absorption Spectrophotometric Method \\
12 & Copper & Atomic Absorption Spectrophotometric Method \\
13 & Sodium & Flame Photometric Method \\
\hline
\end{tabular}

Preparation of extracts:

The extract was prepared as mentioned in Murthy et $a l^{7}$. The crushed seeds powders of Mucuna sps were immersed in water and the flasks were kept at $40^{\circ} \mathrm{C}$ in a heating water bath overnight. The following day the extract was filtered through muslin cloth and kept in Lyophilizer (Labconco Freezone 4.5 , at $-50^{\circ} \mathrm{C}$, $0.020 \mathrm{mbar}$ ) to concentrate further. The dried, powered forms of these extracts were preserved at dark and cold place to maintain the medicinal value till further use.

\section{Experimental animals:}

Sixty six Sprague Dawley strain male rats were procured and acclimatized for one week in experimental room after veterinary examination. They were housed in clean poly propylene cages obtaining approval of Institutional Animal Ethics Committee (IAEC) meeting held on $26^{\text {th }}$ September 2013, with approval code number TI003 as per guidelines of the CPCSEA.

\section{Experimental design:}

Male rats were divided into 11 groups (Group IXI) comprising of six animals in each group. Group I (Control) received distilled water and normal rat chow. Group II (Standard) received L-Dopa at 20 $\mathrm{mg} / \mathrm{kg}$ orally. While Group III, IV, and V received 100,200 and $400 \mathrm{mg} / \mathrm{kg}$ of $M$. cochinchinensis (Black seed variety) aqueous extract orally, respectively. Similarly, Group VII, VIII, and VIII received 100, 200, and $400 \mathrm{mg} / \mathrm{kg}$ of $M$. cochichinensis (White seed variety) aqueous extract orally, respectively. Group IX, X, and XI received 100, 200, and $400 \mathrm{mg} / \mathrm{kg}$ of $M$. pruriens aqueous extract orally. All the animals were 
Table 1: Elemental analysis of Mucuna sps.

\begin{tabular}{ccccc}
\hline Sr. No. & Parameters & $\begin{array}{c}\text { M. pruriens (L.) } \\
\text { DC. }\end{array}$ & $\begin{array}{c}\text { M. cochinchinensis } \\
\text { (Lour.) A. Chev. (White } \\
\text { Seed) }\end{array}$ & $\begin{array}{c}\text { M. cochinchinensis } \\
\text { (Lour.) A. Chev. (Black } \\
\text { Seed) }\end{array}$ \\
\hline 1 & & $5.22 \%$ & $4.25 \%$ & $4.61 \%$ \\
2 & Nitrogen & $0.35 \%$ & $0.32 \%$ & $0.32 \%$ \\
3 & Phosphorus & $1.15 \%$ & $1.20 \%$ & $1.10 \%$ \\
4 & Potassium & $0.024 \%$ & $0.016 \%$ & $0.020 \%$ \\
5 & Calcium & $0.19 \%$ & $0.16 \%$ & $0.18 \%$ \\
6 & Sagnesium & $0.29 \%$ & $0.26 \%$ & $0.21 \%$ \\
7 & Sulphur & $19 p p m$ & $18 \mathrm{ppm}$ & $15 \mathrm{ppm}$ \\
8 & Iron & $29 \mathrm{ppm}$ & $5 \mathrm{ppm}$ & $16 \mathrm{ppm}$ \\
9 & Manganese & $40 \mathrm{ppm}$ & $34 \mathrm{ppm}$ & $32 \mathrm{ppm}$ \\
10 & Zinc & $18 \mathrm{ppm}$ & $19 \mathrm{ppm}$ & $15 \mathrm{ppm}$ \\
11 & Copper & $0.25 \%$ & $0.20 \%$ & $0.20 \%$ \\
\hline
\end{tabular}

Table - 2: Group mean body weight (gm)

\begin{tabular}{|c|c|c|c|c|c|c|c|c|c|}
\hline Group & $\begin{array}{l}\text { Dose } \\
\mathrm{mg} / \mathrm{kg}\end{array}$ & Sample & & 0 & 7 & 14 & 21 & 28 & 30 \\
\hline \multirow{2}{*}{ I } & \multirow{2}{*}{0} & \multirow{2}{*}{ Control } & Mean & 260.67 & 274.33 & 287.50 & 301.67 & 315.33 & 320.17 \\
\hline & & & $\pm S D$ & 8.55 & 9.14 & 9.48 & 9.61 & 9.95 & 10.89 \\
\hline \multirow{2}{*}{ II } & \multirow{2}{*}{20} & \multirow{2}{*}{ L-Dopa } & Mean & 261.00 & 287.67 & 302.33 & 317.17 & 332.00 & 340.33 \\
\hline & & & $\pm S D$ & 8.65 & 6.95 & 7.37 & 7.78 & 7.07 & 6.06 \\
\hline \multirow{2}{*}{ III } & \multirow{2}{*}{100} & \multirow{6}{*}{$\begin{array}{c}\text { Mucuna } \\
\text { cochinchinensis } \\
\text { (Black seed) }\end{array}$} & Mean & 258.33 & 269.83 & 282.00 & 294.00 & 305.67 & 309.83 \\
\hline & & & $\pm S D$ & 9.07 & 7.96 & 8.07 & 7.87 & 8.52 & 8.40 \\
\hline \multirow{2}{*}{ IV } & \multirow{2}{*}{200} & & Mean & 260.33 & 272.50 & 285.50 & 298.00 & 310.17 & 314.67 \\
\hline & & & $\pm S D$ & 3.88 & 4.09 & 4.09 & 4.15 & 4.17 & 3.93 \\
\hline \multirow{2}{*}{ V } & \multirow{2}{*}{400} & & Mean & 258.67 & 279.17 & 289.67 & 309.33 & 321.17 & 337.17 \\
\hline & & & $\pm S D$ & 7.97 & 5.49 & 3.56 & 12.21 & 6.68 & 7.86 \\
\hline \multirow{2}{*}{ VI } & \multirow{2}{*}{100} & \multirow{6}{*}{$\begin{array}{c}\text { Mucuna } \\
\text { cochinchinensis } \\
\text { (White seed) }\end{array}$} & Mean & 261.00 & 273.33 & 286.50 & 299.33 & 312.33 & 316.67 \\
\hline & & & $\pm S D$ & 5.48 & 5.39 & 5.68 & 6.12 & 6.22 & 6.65 \\
\hline \multirow{4}{*}{ VIII } & \multirow{2}{*}{200} & & Mean & 259.33 & 271.67 & 284.00 & 296.50 & 308.33 & 312.00 \\
\hline & & & $\pm S D$ & 6.65 & 6.68 & 6.39 & 5.92 & 6.02 & 5.37 \\
\hline & & & Mean & 260.00 & 271.50 & 283.83 & 296.50 & 307.67 & 311.17 \\
\hline & 400 & & $\pm S D$ & 8.20 & 8.29 & 8.08 & 7.97 & 7.97 & 7.52 \\
\hline \multirow{2}{*}{ IX } & \multirow{2}{*}{100} & \multirow{6}{*}{ Mucuna pruriens } & Mean & 261.33 & 273.83 & 286.67 & 299.83 & 312.50 & 318.33 \\
\hline & & & $\pm \mathrm{SD}$ & 5.16 & 5.04 & 5.09 & 5.38 & 5.89 & 6.65 \\
\hline \multirow{2}{*}{$x$} & \multirow{2}{*}{200} & & Mean & 260.00 & 273.00 & 286.33 & 299.67 & 312.83 & 320.17 \\
\hline & & & $\pm S D$ & 5.80 & 5.80 & 5.82 & 5.82 & 6.01 & 6.82 \\
\hline \multirow{2}{*}{$X I$} & \multirow{2}{*}{400} & & Mean & 261.33 & 283.83 & 294.00 & 315.17 & 324.17 & 331.17 \\
\hline & & & $\pm \mathrm{SD}$ & 5.16 & 4.54 & 4.00 & 5.71 & 3.19 & 9.15 \\
\hline
\end{tabular}

treated orally with the drug for 30 days. The weekly body weight of all the animals was measured upto 30 days of the experimental period.

\section{Collection and processing of blood samples:}

Blood samples were collected from all the animals by orbital bleeding from ether anesthetized animals after 30 days of the treatment. Approximately $1-1.5 \mathrm{ml}$ of blood was collected from all rats in each group including the control group. The samples were carefully introduced into containers free from anticoagulant and properly labeled. The blood samples were allowed to clot, retract and then centrifuged for 5 minutes at a speed of 5000 revolutions per minute.

Biochemical Analysis:

The collected serum was refrigerated at $-20^{\circ} \mathrm{C}$ to carry out testosterone, estradiol, Luteinizing hormone (LH), and Total Antioxidant Capacity (TAC) analysis using kit based assays (Biovision, California, US). 
Table -3 Effect of treatment on weight of testes, epididymis, sperm count, sperm motility, sperm morphology in rats.

\begin{tabular}{|c|c|c|c|c|c|c|c|c|c|c|c|c|}
\hline \multirow[t]{2}{*}{ Parameters } & \multirow{2}{*}{$\begin{array}{c}\text { Group } \\
\text { \& } \\
\text { Dose } \\
\text { (mg/ } \\
\text { kg) }\end{array}$} & \multirow{2}{*}{$\begin{array}{l}\text { Control } \\
\text { G1 } \\
0\end{array}$} & \multirow{2}{*}{$\begin{array}{c}\text { L- } \\
\text { Dopa } \\
\text { G2 } \\
20\end{array}$} & \multicolumn{3}{|c|}{$\begin{array}{l}\text { M. cochinchinensis } \\
\text { (Black seed variety) }\end{array}$} & \multicolumn{3}{|c|}{$\begin{array}{l}\text { M. cochinchinensis } \\
\text { (White seed variety) }\end{array}$} & \multicolumn{3}{|c|}{ M. pruriens } \\
\hline & & & & $\begin{array}{c}\text { G3 } \\
100\end{array}$ & $\begin{array}{c}\text { G4 } \\
200\end{array}$ & $\begin{array}{l}\text { G5 } \\
400\end{array}$ & $\begin{array}{c}\text { G6 } \\
100\end{array}$ & $\begin{array}{c}\text { G7 } \\
200\end{array}$ & $\begin{array}{l}\text { G8 } \\
400\end{array}$ & $\begin{array}{c}\text { G9 } \\
100\end{array}$ & $\begin{array}{l}\text { G10 } \\
200\end{array}$ & $\begin{array}{l}\text { G11 } \\
400\end{array}$ \\
\hline \multirow{2}{*}{$\begin{array}{l}\text { Weight of Testes } \\
\text { (Absolute) }\end{array}$} & ean & & 3.298 & 901 & 3.101 & 3.294 & 2.827 & 883 & 2.936 & 2.899 & 2.915 & 3.220 \\
\hline & & 0.27 & 0.20 & & 017 & & ? & 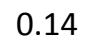 & & 23 & & 0.23 \\
\hline \multirow{2}{*}{$\begin{array}{l}\text { Weight of Testes } \\
\text { (Relative) }\end{array}$} & in & & 0.975 & 2 & & & & & & 0.936 & & \\
\hline & & & 0.04 & & & & & & & 0.08 & & \\
\hline & 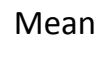 & & 0.88 & & & & 0.6 & & & .70 & & \\
\hline $\begin{array}{l}\text { Epid } \\
\text { (Abs }\end{array}$ & & 0 & 0.04 & 0.03 & 0.02 & 0.05 & 0 & & & 0.05 & 6 & 0.10 \\
\hline Weį & & & .250 & & & & & & & 0.225 & & 0.2 \\
\hline $\begin{array}{l}\text { Epic } \\
\text { (Rel }\end{array}$ & & & 0.01 & & & & & L & & 0.01 & ? & 0 \\
\hline Spel & & & 28.83 & 20. & & & & & & & & \\
\hline & & & 1.96 & & & & & & & & & \\
\hline & ean & & 90.58 & 78.92 & 81.58 & 89 & 69 & 73 & & 80.67 & & 88.50 \\
\hline (\%) & & & 4.16 & 5.94 & & & & & & & & \\
\hline Sper & Mean & 77.57 & 85.50 & 75.60 & 79.80 & 84.90 & 69.83 & 72.20 & 75.33 & 70.13 & 73.57 & 84.00 \\
\hline morphology (\%) & $\pm S D$ & 2.32 & 2.51 & 5.11 & 3.50 & 2.20 & 3.79 & 5.53 & 5.87 & 5.24 & 4.35 & 0.89 \\
\hline
\end{tabular}

Table 4: Biochemical rat serum levels of Estradiol, Teststerone, Luteinizing Hormone and Total Antioxidant Capacity in rats treated with aqueous extract of Mucuna sps $(400 \mathrm{mg} / \mathrm{kg}$ body weight)

\begin{tabular}{ccccccc}
\hline $\begin{array}{c}\text { SI. } \\
\text { No. }\end{array}$ & $\begin{array}{c}\text { Name of } \\
\text { chemical } \\
\text { test/assay }\end{array}$ & Control & L-Dopa & $\begin{array}{c}\text { M. } \\
\text { cochinchinensis } \\
\text { (Black) }\end{array}$ & $\begin{array}{c}\text { M. } \\
\text { cochinchinensis } \\
\text { (White) }\end{array}$ & M. pruriens \\
\hline 1 & $\begin{array}{l}\text { Estradiol EIA } \\
\text { Assay }\end{array}$ & $9.548 \pm 0.68$ & $8.654 \pm 0.64$ & $7.49 \pm 0.57$ & $7.996 \pm 0.51$ & $7.669 \pm 0.56$ \\
2 & $\begin{array}{l}\text { Testosterone } \\
\text { ElA assay }\end{array}$ & $225.42 \pm 10.35$ & $380.55 \pm 11.55$ & $377.14 \pm 19.55$ & $338.15 \pm 10.92$ & $350.84 \pm 16.55$ \\
3 & $\begin{array}{l}\text { Luteinizing } \\
\text { hormone EIA } \\
\text { assay }\end{array}$ & $1.04 \pm 0.139$ & $1.575 \pm 0.138$ & $1.367 \pm 0.158$ & $1.288 \pm 0.142$ & $1.453 \pm 0.145$ \\
4 & $\begin{array}{l}\text { Total } \\
\text { Antioxidant } \\
\text { Capacity Assay }\end{array}$ & $13.31 \pm 1.92$ & $13.87 \pm 1.55$ & $15.232 \pm 1.81$ & $14.991 \pm 1.67$ & $21.066 \pm 1.86$ \\
\hline
\end{tabular}

\section{Histopatholgical study:}

After completion of experimental duration, animals were sacrificed and testes were isolated and absolute and relative weight of testes and epididymis was measured. The sperm count, motility and morphology of sperm in all the animals were noted. The isolated testes were kept in specimen bottle containing Bouin fluid solution and processed for paraffin sectioning. Sections of $5 \mu$ thickness were prepared and stained with haematoxylin and eosin for microscopic (histology) study of testes.

\section{Statistical analysis:}

The results were expressed as mean \pm SEM. The significance of differences was analyzed using Student's t-test, $\mathrm{p}<0.05$ was considered as significant.

\section{RESULTS AND DISCUSSION}

Elemental Analysis:

The elemental analysis showed that significant levels of zinc, manganese and calcium in seeds of $M$. pruriens followed by $M$. cochinchinensis black 


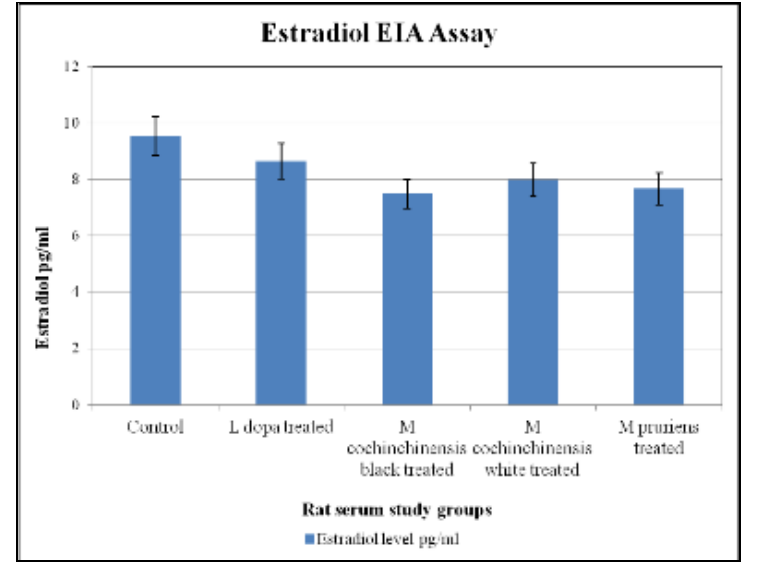

Graph 1: Serum Estradiol level in rat after treatment with aqueous extract of Mucuna sps. $(400 \mathrm{mg} / \mathrm{kg}$ body weight)

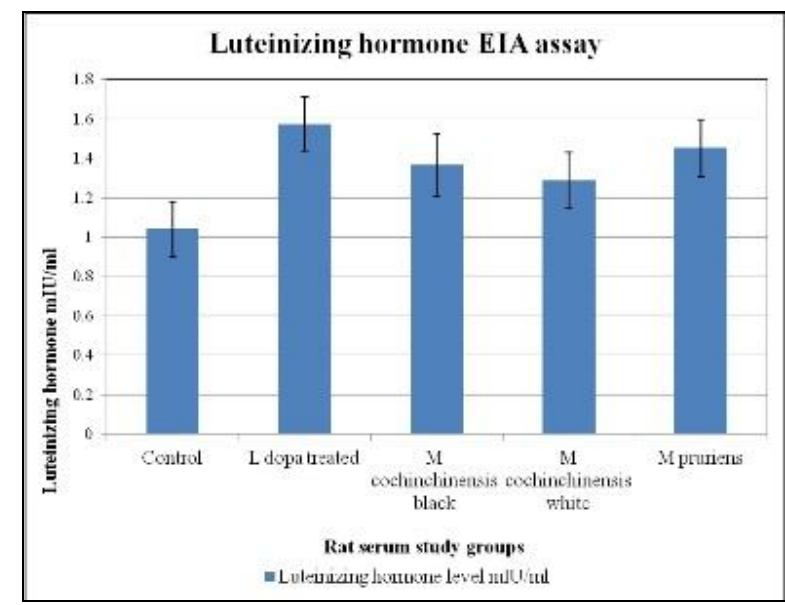

Graph 3: Serum LH level in rat after treatment with aqueous extract of Mucuna sps $(400 \mathrm{mg} / \mathrm{kg}$ body weight)

and white seed variety. The elemental analysis of seeds of Mucuna sps is depicted in Table 1.

Animal study:

There was no incidence of treatment related mortality among the animals exposed to the standard drug and test materials ( $M$. cochinchinensis (Black seed variety), $M$. cochichinensis (White seed variety) and $M$. pruriens) at 100, 200, $400 \mathrm{mg} / \mathrm{kg}$ body weight. Treatment of rats with test materials at all doses did not induce any noticeable treatment related abnormal clinical signs.

\section{Body Weights:}

M. cochichinensis (Black seed variety) and $M$. pruriens at $400 \mathrm{mg} / \mathrm{kg}$ body weight dose and standard drug induce a significant increase in the

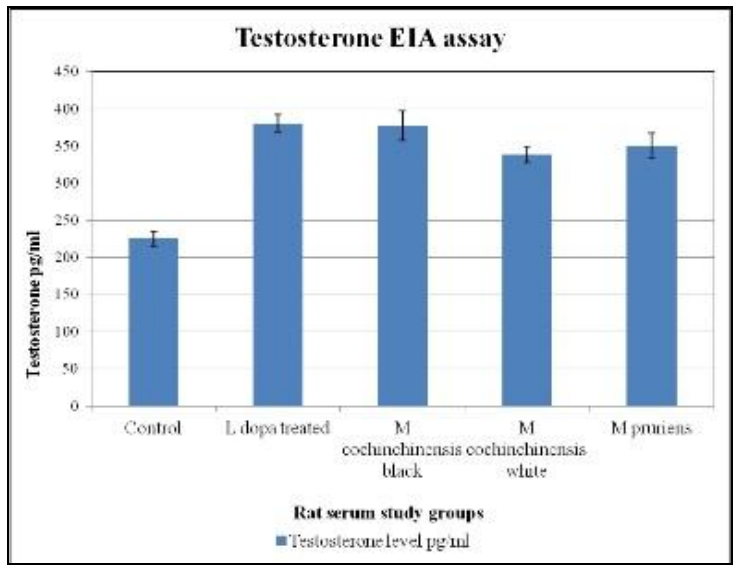

Graph 2: Serum Testosterone level in rats after treatment with aqueous extract of Mucuna sps. (400 $\mathrm{mg} / \mathrm{kg}$ body weight)

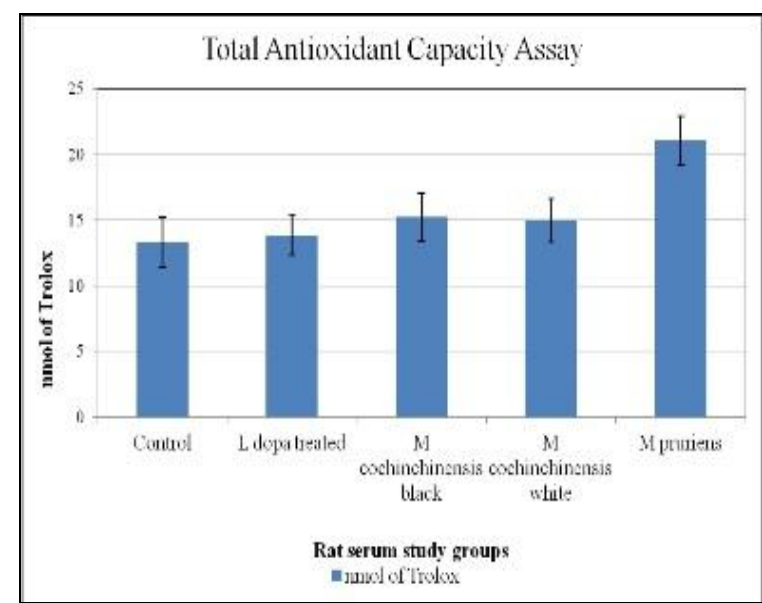

Graph 4: Serum TAC level in rat after treatment with aqueous extract of Mucuna sps $(400 \mathrm{mg} / \mathrm{kg}$ body weight)

group mean body weights of the animals. Other doses at 100 and $200 \mathrm{mg} / \mathrm{kg}$ body weight of test drugs did not induce any observable change in body weight animals (Table 2 ).

\section{Food Consumption:}

The values of average daily food consumption in all groups were comparable with control group of animals.

\section{Necropsy:}

All test materials (M. cochinchinensis (Black seed variety), M. cochichinensis (White seed variety) and $M$. pruriens) at doses of 100, 200 and $400 \mathrm{mg} / \mathrm{kg}$ body weight and standard drug at 20 $\mathrm{mg} / \mathrm{kg}$ dose did not induce any significant treatment related gross histological changes in any of the organs or tissues of treated rats. 


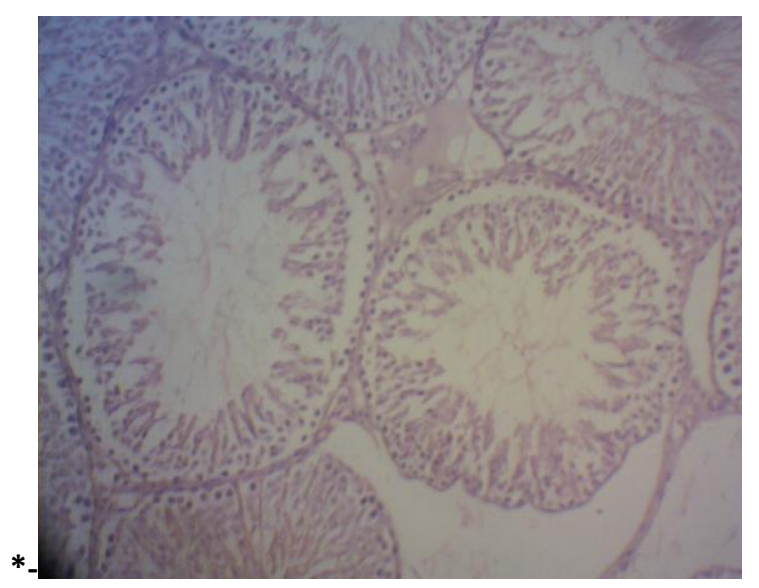

Fig 1. TS of rat testes in Control Group.

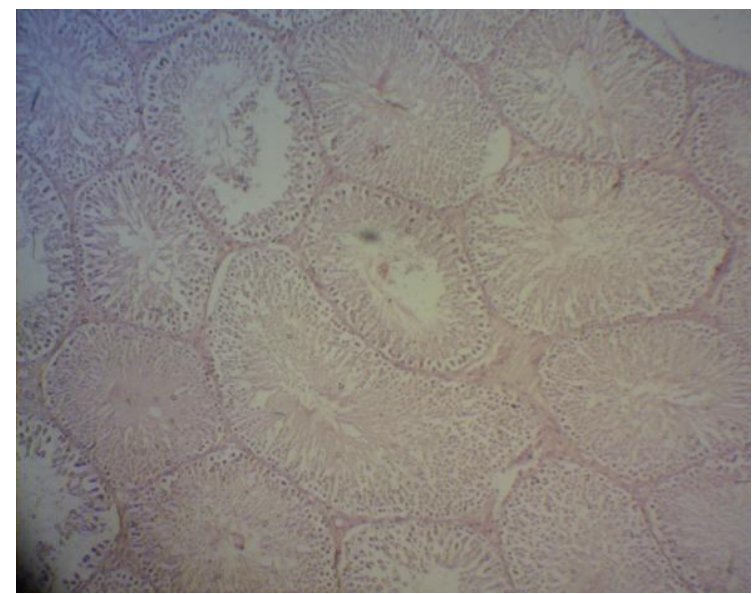

Fig 3. TS of rat testes treated with aqueous extract of Mucuna pruriens at $400 \mathrm{mg} / \mathrm{kg}$ body weight, orally.

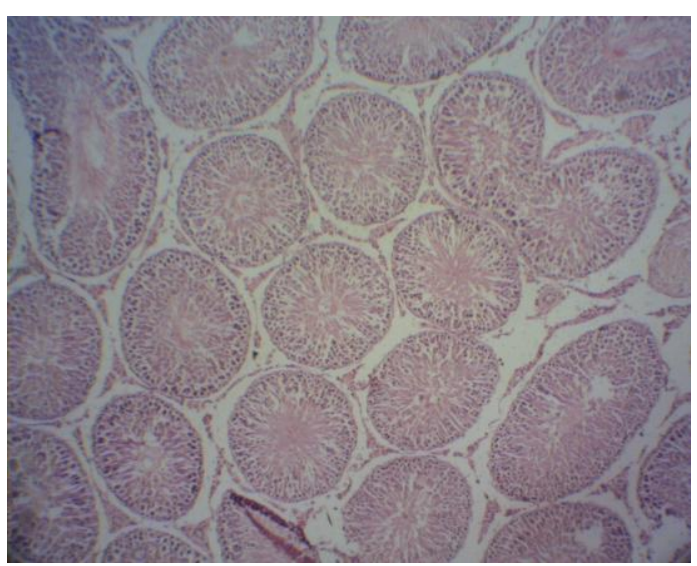

Fig 2. TS of rat testes treated with aqueous extract of Mucuna cochinchinensis (Black seed) at $400 \mathrm{mg} / \mathrm{kg}$ body weight, orally.

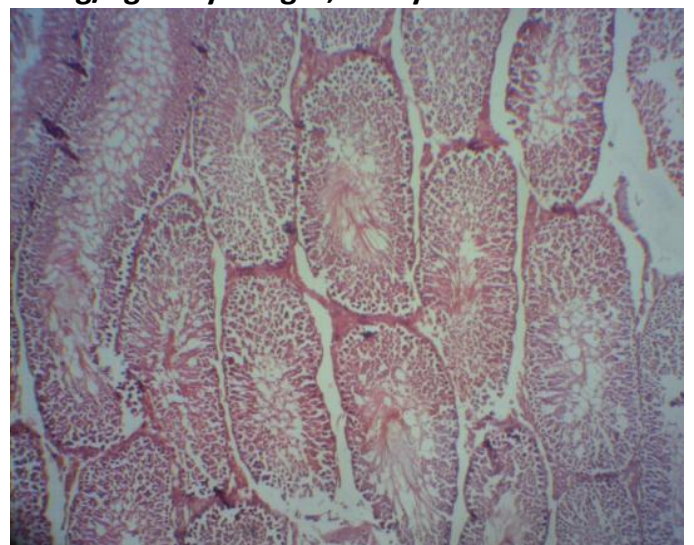

Fig 4. TS of rat testes treated with aqueous extract of Mucuna cochinchinensis (White seed) at $400 \mathrm{mg} / \mathrm{kg}$ body weight, orally.

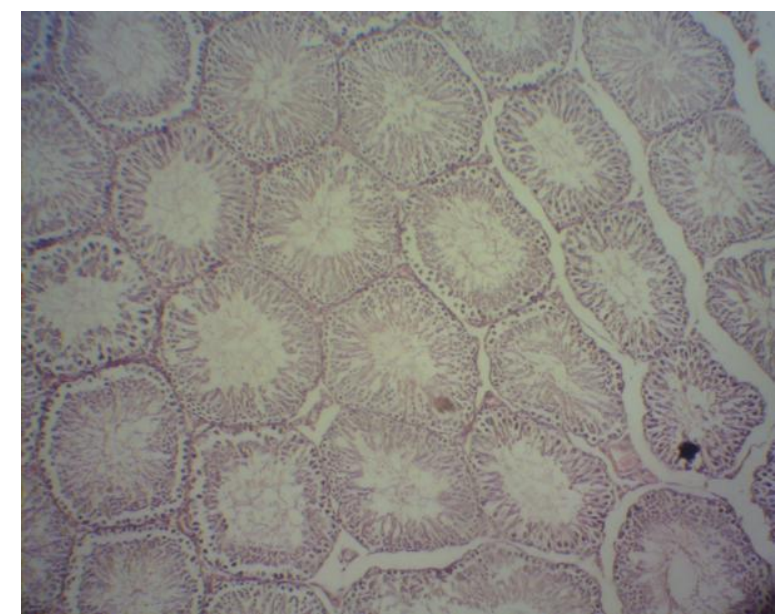

Fig 4. TS of rat testes treated with L-Dopa at $20 \mathrm{mg} / \mathrm{kg}$ body weight, orally.

Weights of Organs:

Increase in absolute and relative weights of testes and epididymis in group II, VIII and XI animals was found to be statistically significant $(p<0.05)$ when compared with control group of animals (Table 3 ).
Sperm count, motility and morphology of sperm:

Treatment with the standard drug at $20 \mathrm{mg} / \mathrm{kg}$ and $M$. cochichinensis (Black seed variety) and $M$. pruriens at $400 \mathrm{mg} / \mathrm{kg}$ body weight for 30 days induces a significant increase in sperm count, 
motility and morphology of sperms $(p<0.05)$ (Table 3).

\section{Biochemical Analysis:}

The rat serum levels of testosterone, luteinizing hormone and total antioxidant capacity showed significant increase after treatment with the aqueous extracts of $M$. cochinchinensis (Black seed variety), $M$. cochichinensis (White seed variety) and $M$. pruriens at $400 \mathrm{mg} / \mathrm{kg}$ body weight for 30 days as compared to the normal control animals. The increase in serum levels of these biochemical parameters was comparable with those of L-Dopa treated animals. The level of rat serum estradiol in the treatment group was declined as compared to the normal control animals (Table 4 and Graph 1-4).

\section{Histological section:}

The histological cross sections of testes in the control group showed normal histological texture (Fig 1). Cross section of testes in the aqueous extract treated groups with $400 \mathrm{mg} / \mathrm{kg}$ body weight of $M$. cochinchinensis (black seed variety) revealed more number of seminiferous tubules having maximum diameter, large number of different cells (sertoli, leydigs cells) at various stages of spermatogenesis and spermatozoa in seminiferous tubules (Fig 2). This profile was followed by sections of testes treated with $M$. pruriens and $M$. cochinchinensis white seed variety (Fig 3-4).

\section{DISCUSSION}

In spermatogenesis and recovery of endocrine axis, the role of L-3, 4-dihydroxy phenylalanine ( $L$ Dopa) is well known from the earlier studies. Ldopa, a non-protein amino acid, stimulates the hypothalamus and forebrain which leads to the production of gonadotropin releasing hormone. Gonadotropin releasing hormone activates anterior lobe of pituitary for secretion of FSH and $\mathrm{LH}$ which in turn leads to activation of thuriens ${ }^{5,7}$.

In the treatment of Parkinson's disease L-dopa acts as precursor for the neurotransmitter dopamine ${ }^{8-11}$. Dopamine mediates L-dopa induced facilitation of sexual behavior in male rats.

Our previous study showed that Mucuna cochinchinensis (black seed variety) was found to have highest L-dopa content of $190.71 \mu \mathrm{g} / \mathrm{ml}$, followed by $M$. cochinchinensis - white seed variety $(96.22 \mu \mathrm{g} / \mathrm{ml})$ and $M$. pruriens $(77.68$ $\mu \mathrm{g} / \mathrm{ml})^{7}$.

In the present study, $M$. cochinchinensis black variety showed significant spermatogenetic activity which may be correlated with the presence of high amount of L-dopa as compared to other species of Mucuna studied.

Kapikachu (Mucuna sps) is being used for it's spermatogenetic (Vrishya) activity for centuries by Ayurvedic scholars, which is established through this study. This activity can be attributed to the presence of high levels of L-dopa. During this study it was also observed that spermatogenic effect of administration of L-dopa alone, as standard, to the animals could not produce the results on par with the aqueous extract of Mucuna sps treated animals. This could be due to the presence of zinc $^{12}$ and other phytoconstituents of the seeds ${ }^{13}$.

Shukla et al. ${ }^{2}$ had reported that on treatment with $M$. pruriens in infertile men there was a significant improvement in serum testosterone, luteinizing hormone, dopamine, adrenaline, and noradrenaline levels and reduced levels of follicle stimulating hormone (FSH) and prolactine hormone (PRL). Sperm count and motility were significantly recovered in infertile men. In the present study also similar observations were seen in rats treated with Mucuna extracts. M. pruriens seed powder rejuvenates the harmonic balance of male reproductive hormones in infertile men and reactivates the enzymatic activity of metabolic pathways and energy metabolism ${ }^{14}$.

\section{CONCLUSION}

The data obtained in this study revealed that spermatogenesis and sperm parameters significantly changes during treatment with high dose of Mucuna cochinchinensis (Black seed) followed by Mucuna pruriens and Mucuna cochichinensis (White seed) in rats.

\section{ACKNOWLEDGEMENT}

We gratefully acknowledge the moral support extended by Dr. K.S. Dhiman, Director General, Central Council of Research in Ayurveda and Siddha. New Delhi, India, for the present study.

\section{REFERENCES}

1. Vagbhata, Astanga Samgraha', edited by Atrideva Vaidya Pankara, Bansa Pathaka, Varanasi, (1975).

2. Shukla KK, Mahdi AA, Ahmad MK, Jaiswar SP, Shankwar SN, Tiwari SC. Mucuna pruriens Reduces Stress and Improves the Quality of Semen in Infertile Men . Evidence-Based Complementary and Alternative Medicine. 2010;7(1):137-44. Available from: http://dx.doi.org/10.1093/ecam/nem171.

3. Jadhav SR, Physiological study of Shukravaha Srotas and clinical study of kapikacchu Churna in Klaibya 
with special Ref. to oligozoospermia (Thesis), PG Dept. Of Sharir kriya, NIA Jaipur. 2013; 141-145.

4. Jadhav SR, Dadhich OP, \& Kothari P, KAPIKACCHU (Mucuna pruriens) - A Ayurvedic drug review, World J Pharm Sci. 2015; 3(10):1999-2003. http://www.wjpsonline.org/issue.php?id=MzM

5. Singh AP, Sarkar S, Tripathi M, Rajender S. Mucuna pruriens and Its Major Constituent L-DOPA Recover Spermatogenic Loss by Combating ROS, Loss of Mitochondrial Membrane Potential and Apoptosis. Vavvas D, editor. PLoS ONE. 2013 Jan 22;8(1):e54655. Available from: http://dx.doi.org/10.1371/journal.pone.0054655.

6. Khaki A, Fathiazad F, Nouri M, Khaki AA, Ozanci CC, Ghafari-Novin M, \& Hamadeh $M$. The Effects of Ginger on Spermatogenesis and Sperm parameters of Rat. Iranian J. of Reproductive Med. 2009; 7(1):7-12.

https://scholar.google.co.in/citations?view op=vie w citation\&hl=en\&user=eHppksIAAAAJ\&citation $f$ or view=eHppksIAAAAJ:fbc8zXXH2BUC

7. Murthy S. N., Malgaonkar MM, Shirolkar AR, Pawar SD, Sangvikar S, \& Kulkarni YR. A comparative assessment of pharmacologically active principles and antioxidant activity of commonly occurring Mucuna sps. in India. International Journal of Ayurveda and Pharma Research. 2015; 3(11):8-13. http://ijapr.in/index.php/ijapr/article/view/2/17

8. Daxenbichler ME, VanEtten $\mathrm{CH}$, Hallinan $\mathrm{EA}$, Earle FR, Barclay AS. Seeds as sources of L-Dopa. Journal of Medicinal Chemistry. 1971 May;14(5):463-5.
Available

from: http://dx.doi.org/10.1021/jm00287a030.

9. Anonymous (1973) British Pharmacopoeia, London.

10. Manyam BV. An alternative medicine treatment for Parkinson's disease: results of a multicenter clinical trial - HP-200 in Parkinson's disease study group. J. Alternat. Comp. Med. 1995; 1 : 249-255.

11. Longhi JG, Perez E, Lima JJ de, Cândido LMB. In vitro evaluation of Mucuna pruriens (L.) DC. antioxidant activity. Braz J Pharm Sci. 2011 Sep;47(3):535-44. Available from: http://dx.doi.org/10.1590/s198482502011000300011.

12. Cheah $Y$, Yang W. Functions of essential nutrition for high quality spermatogenesis. ABB. 2011;02(04):182-97. Available from: http://dx.doi.org/10.4236/abb.2011.24029.

13. Murthy SN, Sangvikar S, Malgaonkar MM, Sharma C \& Kulkarni YR. In vitro physicochemical, phytochemical and fluroscence assessment of Mucuna sps. IOSR Journal of Biotechnology and Biochemistry. 2016; 2(2):1-10. http://iosrjournals.org/ iosr-jbb/papers/Vol2ssue2/A0220110.pdf

14. Gupta A, Mahdi AA, Ahmad MK, Shukla KK, Bansal $\mathrm{N}$, Jaiswer $\mathrm{SP}$, et al. A proton NMR study of the effect of Mucuna pruriens on seminal plasma metabolites of infertile males. Journal of Pharmaceutical and Biomedical Analysis. 2011 Jul;55(5):1060-6. Available from: http://dx.doi.org/10.1016/j.jpba.2011.03.010. 